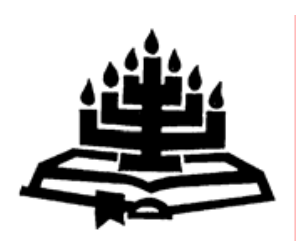

\title{
The metaphor of Yahweh as healer in the prophetic books of the Old Testament ${ }^{1}$
}

\author{
D.F. O'Kennedy \\ Department of Old and New Testament \\ University of Stellenbosch \\ STELLENBOSCH \\ E-mail: danieok@nghelder.co.za
}

\begin{abstract}
The metaphor of Yahweh as healer in the prophetic books of the Old Testament

Yahweh as healer is not a major metaphor in the Old Testament, but it nevertheless plays a significant role in the prophetic books. In many instances this metaphor is conveyed by the Hebrew root רפו with Yahweh as subject. This article offers a few possible responses to the following question: How did the prophets portray Yahweh as healer? According to the prophets, Yahweh's healing was more than a medically verifiable physical process. The prophetic books focus more on the spiritual healing of Israel and Judah than on the physical healing of an individual (cf. Is. 57:18-19; Jer. 3:22; 30:17; Hos. 14:5 [4]). In some instances Yahweh offered comprehensive deliverance or concrete promises for a "sick" nation. This comprehensive healing includes the rebuilding of the city and temple, forgiveness of sins, joy and prosperity (Jer. 30:17; 33:6; Ezek. 47:8-12). Yahweh's healing was not restricted to his elected people alone; he even offered healing to Egypt (Is. 19:22) and Babylon (Jer. 51:8-9).
\end{abstract}

1 A longer version of this article was published in Horizons in Biblical theology $(2005,27(1): 87-113)$ under the title "God as healer in the prophetic books of the Hebrew Bible". The editor gave permission that this revised shorter version could be published in an accredited South African journal. 


\section{Opsomming}

\section{Die metafoor van Jahwe as geneser in die profetiese boeke van die Ou Testament}

Die metafoor van Jahwe as geneser is nie 'n sentrale metafoor in die Ou Testament nie, maar dit vervul tog 'n belangrike rol in die profetiese boeke. Hierdie artikel bied 'n paar moontlike antwoorde op die volgende vraag: Hoe het die Ou-Testamentiese profete Jahwe as geneser of heler uitgebeeld? In baie gevalle word die metafoor deur die Hebreeuse werkwoord wפ met Jahwe as subjek oorgedra. Volgens die profete behels Jahwe se genesing meer as blote fisiese genesing. The profetiese boeke fokus meer op die geestelike genesing van Israel en Juda as op die fisiese genesing van 'n individu (vgl. Jes. 57:18-19; Jer. 3: 22; 30:17; Hos. 14:5 [4]). In sommige gevalle bied Jahwe omvatende verlossing of konkrete beloftes vir 'n "siek" volk. Hierdie omvattende genesing of gesondmaking sluit die volgende in: die herbou van die stad en tempel, vergifnis van sonde, en vreugde en voorspoed (Jer. 30:17; 33:6; Eseg. 47:8-12). Jahwe se genesing was nie beperk tot sy uitverkore volk nie. Hy het selfs genesing vir Egipte (Jes. 19:22) en Babilon aangebied (Jer. 51:8-9).

\section{Introduction}

The Old Testament employs many metaphors for Yahweh because no single metaphor can describe everything about Israel's God: Yahweh as judge, king, warrior, father, artist, gardener-vinedresser, mother, shepherd, et cetera. Yahweh as healer is not a major metaphor in the Old Testament, but it nevertheless plays a significant role in the prophetic books (Brueggemann, 1997:230-261). ${ }^{2}$ In most instances the healer metaphor is conveyed by the Hebrew root רפ with Yahweh as subject; however, there are several other verbs and nouns that form the semantic domain of the healer metaphor. 3

2 This article does not focus on all the prophetic literature in the Old Testament. The term prophetic books used in this article refers to the classical prophetic books from Isaiah to Malachi and does not include the "former prophets" from the Hebrew Bible (Joshua to 2 Kings).

3 The following Hebrew roots refer to health and healing: גהה (to gather or remove); עלה together with ארוכה (health restored or repair); חבש (to bind up, bandage a wound); חיה (live, put to life, revive, heal); חלם (to be or become healthy and strong; restore to health); מתם (soundness); שובם, especially with the noun נפש (return to health, restore, refresh, keep alive); שלם (peace, health, wellbeing or wholeness) (Seybold, 1980:401; Brown, 1995:28-36; Chan, Song \& Brown, 1997:1162-1173; Wilkinson, 1998:11, 53). See also Hasel, (1983:191- 
According to Wilkinson (1998:53) most of them contain the idea of restoration of something to its previous normal state, or the removal of something which is causing ill-health or an abnormal condition.

\section{Occurrence of רפא in the prophetic books of Isaiah to Malachi}

This article acknowledges the use of other terms and phrases, but will focus on the use of רפו, the most important Hebrew term. The Old Testament usage of the root 1 are 67 times as a verb and nineteen times in derived nominal forms. The verb רפא occurs 30 times in the prophetic books: Thirteen times in the book of Jeremiah (Jer. 3:22; 6:14; 8:11; 8:22; 15:18; 17:14 [2x]; 19:11; 30:17; 33:6; $51: 8 ; 51: 9$ [2x]); seven times in the book of Isaiah (Is. 6:10; 19:22 [2x]; 30:26; 53:5; 57:18; 57:19); five times in the book of Hosea $(5: 13 ; 6: 1 ; 7: 1 ; 11: 3 ; 14: 4[5 x]) ; 4$ four times in the book of Ezekiel (Ezek. 34:4; 47:8; 47:9; 47:11); and once in the book of Zechariah (Zech. 11:16) (Brown, 1995:25; 2004:597; Stoebe, 1997: 1255).

The question may be posed: How many times in the prophetic books do the stem רפא refer to Yahweh as healer? Seventeen of these instances refer directly to Yahweh as the subject of healing (Is. 19:22 [2x]; 30:26; 57:18, 19; Jer. 3:22; 17:14 [2x]; 30:17; 33:6; 51:8, 9 [2x]; Hos. $6: 1 ; 7: 1 ; 11: 3 ; 14: 4[5]) .5$ Some of the other references may indirectly speak of Yahweh as healer but do not state it clearly. In the following section we shall discuss the portrayal of Yahweh as healer focusing on the use of the stem רפא.

\section{The depiction of Yahweh as healer in the prophetic books}

In this section we shall make a distinction between different types or ways of healing, but we accept the fact that there is a close

202) and Kee (1992:659-664) for a more detailed discussion of the semantic field of the healer metaphor.

$4 \quad$ We see several references in Jeremiah and Hosea. There is a strong possibility that Hosea influenced Jeremiah, especially if one compares healing passages like Jeremiah 3:22 and Hosea 14:5 (Petersen, 2002:132-133).

5 The Hebrew reference is always placed first with the NRSV in brackets. All English citations in this article are taken from the NRSV of the Bible. 
relationship between them and that healing must be seen in a comprehensive manner. 6

\subsection{Yahweh as healer of physical sickness}

Isaiah 38:1-207 is probably the only passage in the prophetic books referring to the physical healing of an individual, king Hezekiah. The question may be posed: Why did Yahweh heal king Hezekiah? Why only a reference to a king and not to other people. Two possible responses may be given: the king was seen as the representative of the people of the city (cf. Is. 38:6), or King Hezekiah was a descendant of David and one of the most faithful kings of Judah (Is. 38:3, 5; Wildberger, 2002:466). An interesting element in this text is the role played by the prophet Isaiah. According to Isaiah 38:1 the prophet Isaiah proclaimed that Hezekiah would die and told him to get his house in order. King Hezekiah did not want to accept the prophet's words, put his trust in Yahweh and prayed for recovery (Is. 38:2-3). Yahweh healed him and added fifteen years to his life. Although this passage focused on Hezekiah's physical healing, verse 6 also speaks about a more comprehensive healing. Yahweh promised healing and deliverance for Hezekiah and the city. One cannot exclude the metaphorical use of this passage. Clements (1985:127) says that the prayer in Isaiah 38 is to be understood "both literally in reference to an illness which befell the king but also metaphorically of the unease and spiritual confusion which had stricken his kingdom".

In Jeremiah 17:14 the prophet prays that Yahweh must heal him ("Heal me, O Lord"). According to Lundbom (1999:798) Jeremiah's wound is personal (Jer. 15:8), but one he shares with the people (Jer. 8:21). It is uncertain whether Jeremiah 17:14 refers to Jeremiah's physical healing or his spiritual healing. The fact is that the prophet experienced Yahweh as healer and savior (Simundson, 1982:334).

6 Chan, Song and Brown (1997:1166) argue that the healing of physical diseases was certainly not excluded from the wider metaphor of national healing and restoration.

7 One finds a parallel passage in 2 Kings 20:1-11 and a brief reference of Hezekiah's healing in 2 Chronicles 32:24-26. Although there is a scarcity of passages referring to physical healing in the classical prophetic books we have several passages in the "former prophets" (Cf. 1 Kings 17:21-22; 2 Kings 4:33-35; 5:1-27; 8:29). 


\subsection{Yahweh as healer of broken relationships}

In most prophetic references words like health and healing have a broader meaning than only restoration of physical health. They are often referring to the reconciliation that will take place between God and his people. Even though God has inflicted the blow, He will take action to renew the relationship and heal the wounds (Simundson, 1982:338). In the Old Testament (especially in the Psalms) bodily sickness is very closely connected with sin and is therefore a manifestation of God's wrath against specific transgressions (Ps. 32:1-4; 38:1-10; 39; Graber \& Müller, 1976:167-168). The prophetic books also portray the "sickness and wounds" (חלי ומכה) of the city and its people (Jer. 6:7b). Six times Jeremiah referred to the im-

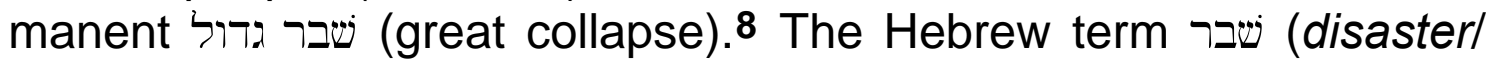
collapse) is the central word used to describe the people's broken condition and one third of the Old Testament occurrences are found in the book of Jeremiah (Brown, 1995:191). Fortunately the Bible does not only focus on sin and the consequences of sin, but portrays Yahweh as healer of sins and broken relationships.

\subsubsection{Repentance, healing and forgiveness}

In some prophetic texts repentance or return (שוב) is seen as a prerequisite for Yahweh's healing (Is. 6:10; 19:22; Jer. 3:22; Hos. 6:1). ${ }^{9}$ However, this cannot be true for all the "healing" passages. Repentance is not always seen as a pre-condition for healing. In Hosea 11 healing and forgiveness are granted despite the fact that Israel kept sacrificing to the Baals and offering incense to idols. The child, Israel, disrespected the love of God her father (cf. Hos. 11:1-3). The divine announcement of healing in Hosea 14:5 (4) cannot be the result of the repentance on the part of the people (Hos. 14:3-4) for the backsliding is still going on. Yahweh's healing and forgiveness are not occasioned by Israel's repentance or her good intentions (Hos. 14:3-4), but springs solely from His generous and free grace. That is exactly what the word נדבה (Hos. 14:5 [4]) wants to emphasise: Yahweh's love is spontaneous, generous and like a freewill offering or voluntary gift (Carpenter \& Grisanti, 1997:31-32; O'Kennedy, 2001:467).

9 Mosis (1989:51) believes that in Isaiah 6:10 and 57:17-18 the root (שוב) depicts the physical return from exile. 
Isaiah 57:17-19 also portrays Yahweh's healing despite Israel's apostasy. The text depicts Yahweh's anger because of their wicked covetousness, but also emphasises that Yahweh will heal them and "repay them with comfort". Jeremiah 30:17 clearly states that Yahweh will restore the health of his people and heal their wounds not because they repented, but because (כ) others had called them outcasts and no one cared for them.

Healing and forgiveness do not stand in opposition to one another. Healing could also be understood as forgiveness and becomes a picture of God's mercy and forgiveness. Stoebe (1997:1257) argues that the verb רפו with Yahweh as subject is filled with a deepened content and also means forgiveness. The term רפא is rarely used in an exclusively spiritual context and in the strict sense of the word at least two רפא verses in the prophetic books refer directly to divine forgiveness, namely Hosea 14:5 (4) and Jeremiah 3:22 (Brown, 1995:381, 387; O'Kennedy, 2001:470). ${ }^{10}$ Besides these two references, Isaiah $53: 5$ also refers indirectly to divine forgiveness. The healing gained for others by the suffering of the servant includes the forgiveness of Israel's sins and the removal of their punishment. This passage summarises Deutero-Isaiah's essential message that Yahweh has forgiven his people and is on the point of restoring them (Whybray, 1981:175-176; Westermann, 1985:263).

One must acknowledge the fact that the other "healing" references do not stand in contrast to Yahweh's forgiveness. They form a broad basis for the understanding of divine forgiveness, and confirm the opinion that Yahweh is a God who grants forgiveness and that forgiveness encompasses more than the removal of sin (O'Kennedy, 1997:104-105).

\subsubsection{Healing after judgment and punishment}

Frequently the prophets refer to Yahweh in terms of divine restoration for the nation after a time of judgment and punishment

10 O'Kennedy (2001:456) mentions three prominent reasons why the verb רפא in Hosea 14:5 (4) may be understood as forgiveness: (1) The verb רפא is used together with the word משובה, expressing the forgiveness of disloyalty; (2) One finds other terms or expressions for forgiveness and mercy in the same passage: נשא עון ("take away/forgive all guilt"), אהבם נדבה ("I will love them freely"); and שב אפי ממנו ("my anger has turned away from them"); (3) Several metaphors appear in Hosea 14:1-10 (9) describing the restored relationship between God and Israel as a result of divine forgiveness: "I will be like the dew to Israel"; "he shall blossom like the lily", et cetera. 
(Is. 6:10; 30:26; Jer. 30:17; Hos. 5:13; 6:1). Yahweh's healing work is matched by his judgment and punishing work, so that Yahweh can heal what he has damaged. This punishment is expressed by different antonyms that are used together with references to Yahweh's healing: שבר (break, smash, fracture);11 מחי (wound, strike) in Isaiah 30:26; נכה (strike, smite) in Isaiah 30:26 and Jeremiah 14:19; חלה (be sick, infirm) in Ezekiel 34:4; and טרף (tear) in Hosea 6:1.

Jeremiah $30: 12-17$ is an interesting poem focusing on healing after a time of judgment and punishment. The first part (Jer. 30:12-15) announces that the sickness and wounds of Israel is incurable because of their sins and Yahweh's punishment. The second part (Jer. 30:16-17) focuses on Yahweh's healing of a nation called an outcast and not cared for (Holladay, 1989:176).

The portrayal of Yahweh as healer is not limited to restoration of what Yahweh has damaged through his judgment. Yahweh's healing capacity pertains to whatever damage has been done, by whatever agent (Brueggemann, 1997:252; Chan, Song \& Brown, 1997:11641165).

\subsection{Yahweh as healer of the land, city and temple}

The healer metaphor does not merely refer to the healing of people. There are a few prophetic texts portraying the healing of the land, city, temple and even God's creation. Sometimes it is difficult to distinguish between people and material things but one can say that Yahweh as healer offered a comprehensive healing of people and material objects. This comprehensive healing includes the physical rebuilding of Jerusalem (Jer. 30:17-18), abundance of prosperity and security (Jer. 33:6), and the restoration of the fortunes of his people (Hos. 6:11-7:1).

Ezekiel 47:1-12 describes different dimensions of Yahweh's comprehensive healing. The prophet visualises water flowing from the threshold of the temple to the Dead Sea. The water becomes deeper as it moves away from its source and gives life and healing wherever it flows. Ezekiel 47:1-12 describes the following: the water sweetens the salty water of the Dead Sea (v. 8); there are all kinds of trees on the bank of the river that will bear fresh fruit $(v .7,12)$; the leaves of the trees are used for healing ( $v .12)$; there are living 
creatures (v. 9) and many fish (v. 9). The water may possibly represent the cosmic river that flows from the temple or the great water source that fertilised Eden (cf. Gen. 2:10-14). At the very least the river is a vivid symbol of the life-giving presence of Yahweh in his temple (Blenkinsopp, 1990:231-232; Block, 1998:696-697). One can pose the question whether the vision in Ezekiel 47:1-12 is describing the healing of the land, temple or creation. It is difficult to make a distinction. We can rather say that this text emphasises the comprehensive healing of Yahweh. Yahweh as healer is present in his temple and will bring healing for the people of the land and his creation.

\subsection{Yahweh as healer for other nations}

Yahweh's healing was not restricted to his elected people alone. There are at least three references focusing on the relationship between Yahweh the healer and other nations, one dealing with $\mathrm{Ba}-$ bylon (Jer. 51:8-9) and two texts referring to Egypt (Is. 19:22; Jer. 46:11).

In Jeremiah 46:11 God, through the prophet, refers to Egypt's search for healing but that it will be in vain. They are summoned to go to Gilead12 for healing medicine. Jeremiah 51:8-9 refer to Yahweh's intention to heal Babylon but she could not be healed:

Suddenly Babylon has fallen and is shattered; wail for her! Bring balm for her wound; perhaps she may be healed. We tried to heal Babylon, but she could not be healed. Forsake her, and let each of us go to our own country; for her judgment has reached up to heaven and has been lifted up even to the skies.

The above-mentioned texts portray Yahweh's intention to heal other nations, but the texts do not say if real healing was accomplished. Isaiah 19:22 is perhaps the only prophetic text referring to "real" healing of another nation. Yahweh promises healing to Egypt after their repentance. In this passage one also finds the dual role of Yahweh as the one who both smites and heals (cf. Is. 57:18-19).

12 Jeremiah 8:21 and 46:11 suppose that there will be balm or healing in Gilead. Gilead on the eastern side of the Jordan river was famous already in patriarchal times as a center for medical resins such as "balsam" (Gen. 37:25; cf. Thompson, 1985:306 and Avalos, 1995:290). 


\subsection{Yahweh, the only God or One who can heal}

The prophetic portrayal of Yahweh as healer differs from the rest of the ancient Near Eastern world. The prophets focused on monotheism, emphasising clearly that it was one God (Yahweh) who both smote and healed (Brown, 1995:238). There are a few prophetic texts focusing on the fact that other gods, nations and kings cannot heal. In Hosea 5:13 one reads the following:

When Ephraim saw his sickness, and Judah his wound, then Ephraim went to Assyria and sent to the great king. But he is not able to cure (רפא) you or heal (גהז) your wound (מזר).

Assyria is understood as the subject of רפא but one can assume that Hosea 5:13 refers indirectly to Yahweh as the healer of Judah and Ephraim. Assyria or the great king of Assyria is not able to heal; therefore Yahweh, the only King of Israel, is the healer. This fact is emphasised if you read Hosea 5:13 together with Hosea 6:1. It is interesting to note that Hosea 5:13 uses two different words to describe the sickness (מזור ; מלי) and the healing of the people (רפה; גהה (גה). This may emphasise the great extent of Israel's sickness and the fact that Assyria is not able to do anything (O'Kennedy, 2001:461). Yahweh alone is healer because He alone is the initiator of the covenant with Israel. When Israel and Yahweh are turned away from one another, the covenant is violated (Sweet, 1982:147).

The prophet Jeremiah proclaims that Yahweh is the only genuine healer. An important text like Jeremiah 17:14 ("Heal me, O Lord, and I shall be healed") is part of a meditation which contrasts trust in humans with trust in Yahweh. Jeremiah 17:5 says "Cursed are those who trust in mere mortals" while Jeremiah 17:7 states "Blessed are those who trust in the Lord". All the other healing passages in Jeremiah emphasise the fact that Yahweh is the real healer (cf. Jer. $30: 17 ; 33: 6)$. There are even sarcastic references to medicine and healers in Gilead, an important medical center in the time of the prophets (Jer. 8:22; 46:11; 51:8-9). The above-mentioned texts indicate that Jeremiah views the human healer as inherently ineffective (Avalos, 1995:287-290).

The prophetic books do not merely contrast Yahweh with humans. It is more appropriate to understand a contrast between Yahweh as Israel's healer and the healing deities of other nations such as Egypt, Assyria and Syria. Yahweh asserts that He is the real healer of his people, not Sekhmet, Marduk, Baal or any other alien god. Yahweh was never sick himself as the other deities could be. The 
gods of Egypt could suffer from disease. When an eclipse of the sun occurred in Egypt it was attributed to an eye disease of the god Ra. This same god nearly died after being stung in his heel by a scorpion. This could never happen to Yahweh, the healthy God of Israel. In contrast to the gods described in the Ugaritic texts, the God of Israel is never subjected to fate or overpowered by disease (Korpel, 1990:337, 341; Brown, 1995:74, 78; Wilkinson, 1998:56).

\subsection{Yahweh as future healer on the Day of the Lord}

The prophetic books are not merely portraying Yahweh as healer in the present time, but also refer to the future. Isaiah 30:26 mentions the alteration of the light from the sun and moon, and the intensification of the sun's light as a sign of God's healing. On the Day of the Lord Yahweh will heal his people's wounds, resulting in the complete restoration for Israel and Judah (cf. Jer. 30:17a; Jer. 33:6; Simondson, 1982:338; Kee, 1992:659-664; Brown, 2004:598).

Malachi announces the coming of a "sun of righteousness" whose chief resource is "healing in its wings" (Mal. 3:20 [4:2]). Hill (1989: 349-350) and O'Brein (2004:313) mention that "sun of rigtheousness" may refer to a divine title for Yahweh, ór merely a figurative description of the eschatological day. We can accept the first hypothesis due to the following reasons: (1) the Old Testament speaks about God as light (Ps. 27:1; Is. 10:17; 60:1, 20; Mic. 7:8) who shines forth when He comes (Deut. 33:2; Ps. 50:2; 94:1; Redditt, 1995:184); and (2) Malachi 3:20-21 (4:2-3) envisioned God's epiphany in the form of the sun with one wing on either side bringing healing. This symbol of the sun pictured as a winged disk was used in the ancient world from Egypt to Persia13 (Petersen, 1995:225226; Clark \& Hatton, 2002:462). Yahweh himself as the "sun of righteousness" would heal his people (i.e. they who revere his name) on the Day of the Lord. One can also compare Malachi 3:20 (4:2) with Isaiah 58:8 another late prophetic text that links light, health and righteousness.

Isaiah 53:5 describes the healing of Israel at the cost of the servant's wounds and bruises. Brown (1995:242) believes that one must understand this verse in its broadest possible term. The prophetic hope was for the whole man to be wholly healed. This is

13 Petersen (1995:225) refers especially to Shamash, the Babylonian sun god. In attributing to Yahweh the characteristics of Shamash Malachi succeeds in underscoring Yahweh's ultimate healing power (O'Brein, 2004:313). 
underscored by the prophetic expectation of the inbreaking of the kingdom of God. Not only would righteousness and peace prevail, but sickness would also disappear (cf. Is. 33:24; 35:1-6; 58:8). The future healing and restoration will not only be for Israel but also for Egypt (Is. 19:22).

\section{Conclusion}

The above discussion has led to the following concluding remarks:

- The Old Testament employs many different metaphors for Yahweh (e.g. Yahweh as father, king, judge, et cetera). Yahweh as healer is not a major metaphor in the Old Testament, but it plays a significant role in the "classical" prophetic books (Isaiah-Malachi). The portrayal of Yahweh as healer was significant for the people of Israel. Sickness and death were viewed in a negative way. Yahweh was the healer and giver of life.

- In many instances the healer metaphor is conveyed by the Hebrew root רפו with Yahweh as subject; however, there are several other verbs and nouns focusing on the healer metaphor (restore, make whole, medicine, balm, disease, wound, sickness, et cetera).

- According to the prophets, Yahweh's healing was more than a medically verifiable physical process. The prophetic books focus more on the spiritual healing of Israel and Judah than on the physical healing of an individual (cf. Is. 57:18-19; Jer. 3:22; 30:17; Hos. 14:5 [4]). Isaiah $38: 1-20$ is probably the only passage in the prophetic books referring to the physical healing of an individual, king Hezekiah.

- Yahweh is seen as the healer of sins and broken relationships. Healing could also be understood as forgiveness. In some prophetic texts repentance and obedience are seen as a prerequisite for Yahweh's healing (Is. 6:10; 19:22; Jer. 3:22; Hos. $6: 1$ ), but there are at least two references that speak of God's healing despite Israel's apostasy (Is. 57:17-19; Hos. 11:1-3). Frequently the prophets refer to Yahweh in terms of divine healing after a time of judgment and punishment (Is. 6:10; 30:26; Jer. 30:17; Hos. 5:13; 6:1).

- The healer metaphor does not merely refer to the healing of people. There are several prophetic texts discussing the healing of the land, city, temple and creation (Is. 30:26; Jer. 30:17-18; 33:6; Ezek. 47:8-12; Hos. 6:11-7:1). 
- Yahweh's healing was not restricted to his elected people alone; He even offered healing to Egypt (Is. 19:22) and Babylon (Jer. 51:8-9).

- The prophetic books depict Yahweh as the only real healer. There are no limits to Yahweh's performance as healer and He cannot be compared with any other person or god. Yahweh is healer in the present time, but will also be a healer in the future (Is. 19:22; 30:26; 53:5; Jer. 30:17; 33:6; Mal. 4:2).

\section{List of references}

AVALOS, H. 1995. Illness and health care in the ancient Near East: the role of the temple in Greece, Mesopotamia and Israel. Atlanta: Scholars Press.

BLENKINSOPP, J. 1990. Ezekiel. Louisville: John Knox. (Interpretation.)

BLOCK, D.I. 1998. The book of Ezekiel 25-48. Grand Rapids: Eerdmans. (New International Commentary on the Old Testament.)

BROWN, M.L. 1995. Israel's divine healer. Grand Rapids: Zondervan. (Studies in Old Testament Biblical Theology.)

BROWN, M.L. 2004. s.v. רפא. Theological dictionary of the Old Testament, 13: 593-602.

BRUEGGEMANN, W. 1997. Theology of the Old Testament: testimony, dispute, advocacy. Minneapolis: Fortress.

CARPENTER, E. \& GRISANTI, M.A. 1997. s.v. נדב. New international dictionary of Old Testament theology and exegesis, 3:31-32.

CHAN, A.K., SONG, T.B. \& BROWN, M.L. 1997. S.v. ארפ. New international dictionary of Old Testament theology and exegesis, 3:1162-1173.

CLARK, D.J. \& HATTON, H.A. 2002. A handbook on Haggai, Zechariah and Malachi. New York: United Bible Societies. (UBS Handbook series.)

CLEMENTS, R.E. 1985. In spirit and truth: insights from Biblical prayers. Atlanta: John Knox.

GRABER, F. \& MÜLLER, D. 1976. s.v. Heal. New international dictionary of New Testament theology, 2:163-172.

HASEL, G. 1983. Health and healing in the Old Testament. Andrews University seminary library, 21:191-202.

HILL, A.E. 1989. Malachi. New York: Doubleday. (Anchor Bible.)

HOLLADAY, W.L. 1989. Jeremiah 2. Minneapolis: Fortress. (Hermeneia.)

KEE, H.C. 1992. s.v. Medicine and healing. Anchor Bible dictionary, 4: 659-664.

KORPEL, M.C.A. 1990. A rift in the clouds: Ugaritic and Hebrew descriptions of the divine. Münster: Ugarit.

LUNDBOM, J.R. 1999. Jeremiah 1-20. New York: Doubleday. (Anchor Bible.)

MOSIS, R. 1989. Umkehr und Vergebung: eine Auslegung von Jer 3:21-4:2. Trierer theologische Zeitschrift, 98:39-60.

O'BREIN, J.M. 2004. Nahum, Habakkuk, Zephaniah, Haggai, Zechariah, Malachi. Nashville: Abingdon Press. (Abingdon Old Testament commentaries.)

O'KENNEDY, D.F. 1997. "It shall not be": divine forgiveness in the intercessory prayers of Amos (Am 7:1-6). Old Testament essays, 10(1):92-108.

O'KENNEDY, D.F. 2001. Healing as/or forgiveness? The use of the term רפא in the book of Hosea. Old Testament essays, 14(3):458-474. 
PETERSEN, D.L. 1995. Zechariah 9-14 and Malachi. Louisville: Westminster. (Old Testament Library.)

PETERSEN, D.L. 2002. The prophetic literature: an introduction. Louisville: Westminster.

REDDITT, P.L. 1995. Haggai, Zechariah, Malachi. Grand Rapids: Eerdmans. (New Century Bible Commentary.)

SEYBOLD, K. 1980. S.v. חלה. Theological dictionary of the Old Testament, 4: 399-409.

SIMONDSON, D.J. 1982. Health and healing in the Bible. Word and world, 2:330-339.

STOEBE, H.J. 1997. S.v. רפא. Theological lexicon of the Old Testament, 3:12541259.

SWEET, A.M. 1982. A theology of healing. The Bible today, 20:145-149.

THOMPSON, J.A. 1985. The book of Jeremiah. Grand Rapids: Eerdmans. (New International Commentary on the Old Testament.)

WESTERMANN, C. 1985. Isaiah 40-66. London: SCM. (Old Testament Library.)

WHYBRAY, R.N. 1981. Isaiah 40-66. Grand Rapids: Eerdmans. (New Century Bible Commentary.)

WILDBERGER, H. 2002. Isaiah 28-39: a continental commentary. Minneapolis: Fortress.

WILKINSON, J. 1998. The Bible and healing: a medical and theological commentary. Grand Rapids: Eerdmans.

\section{Key concepts:}

healing; Old Testament

metaphors for Yahweh

Kernbegrippe:

genesing; Ou Testament

metafore vir Jahwe 
